\title{
STRATEGI MODEL INTERPROFESSIONAL EDUCATION (IPE) TERHADAP PENINGKATAN PENGETAHUAN DAN SIKAP TENTANG KESEHATAN REPRODUKSI REMAJA UNTUK MENCEGAH KEHAMILAN TIDAK DIINGINKAN (KTD) DI SMA NEGERI KOTA PEKALONGAN
}

\author{
Maslikhah ${ }^{1}$, Hilda Prajayanti ${ }^{2}$, Ida Baroroh ${ }^{3}$ \\ Maslikhah_neysa@yahoo.co.id \\ Akademi Kebidanan Harapan Ibu Pekalongan \\ Jl. Sriwijaya No. 7 Kota Pekalongan \\ Telp 085102998866
}

\begin{abstract}
Abstrak
Kehamilan tidak diinginkan (KTD) pada remaja merupakan "fenomena gunung es" karena untuk menggali informasi dan data tersebut cukup sulit karena bersifat rahasia dan tertutup serta menganggap hal tersebut merupakan aib bagi keluarga. Permasalahan Kehamilan Tidak diinginkan (KTD) masa remaja dapat terjadi karena remaja yang sudah memiliki pacar. Masa remaja merupakan masa dimana seseorang ingin mengetahui tentang segala hal baru terutama dengan kesehatan reproduksi dan seksualitas. Biasanya remaja melakukan hubungan seksual dengan satu pasangan. Remaja yang melakukan hubungan seksual sangat berisiko untuk terjadi kehamilan tidak diinginkan (KTD) pada saat remaja dan dapat berlanjut pada putus sekolah. IPE (Interprofesional Education) merupakan metode diskusi kasus yang melibatkan petugas kesehatan baik perawat maupun bidan untuk memberdayakan kader teman sejawat di tatanan sekolah. Tujuan penelitian ini untuk mengetahui pengaruh model interprofesional education (IPE) terhadap peningkatan pengetahuan dan sikap remaja tentang kesehatan reproduksi dalam pencegahan kehamilan tidak diinginkan (KTD) di Sekolah Menegah Atas Negeri (SMA N) Kota Pekalongan

Metode penelitian ini adalah pre eksperimental dengan rancangan One Group Pretest Posttest. Jumlah sampel dalam penelitian ini adalah 60 siswa/siswi. Tehnik pengambilan sampel dengan purposive sampling. Instrumen yang digunakan berupa kuesioner, modul Pencegahan Kehamilan Tidak Diinginkn (KTD), Alat peraga organ reproduksi manusia. Analisis data univariate dengan prosentase, analisis bivariate dengan menggunakan non parametrik wilcoxon.

Hasil penelitian menunjukkan bahwa ada perbedaan pengetahuan sebelum dan setelah pemberian IPE dengan nilai $\mathrm{p}$ value $=0,000$ dengan hubungan sedang (nilai korelasi 0,556 ), rata-rata kenaikan pengetahuan 5,25 , ada perbedaan sikap sebelum dan setelah pemberian IPE dengan nilai $p$ value $=0,000$ dengan memiliki hubungan sedang (korelasi 0,549), dan rata-rata kenaikan sikap 4,717. Disarankan untuk menerapkan model Interprofesional Education (IPE) pada kegiatan PMR dan UKS di SMA untuk menguatkan program promosi kesehatan reproduksi remaja.
\end{abstract}

Kata kunci : Interprofesional Education (IPE), Kesehatan reproduksi remaja, Kehamilan tidak diinginkan (KTD).

\section{Pendahuluan}

Kehamilan tidak diinginkan (KTD) pada remaja merupakan "fenomena gunung es" karena untuk menggali informasi dan data tersebut cukup sulit karena bersifat rahasia dan tertutup serta menganggap hal tersebut merupakan aib bagi keluarga.

Hasil survey Perkumpulan Keluarga Berencana Indonesia (PKBI) menyatakan bahwa remaja berusia 13-15 tahun mengaku telah berhubungan seks dengan pacar, dengan meningkatnya kasus seks bebas menyebabkan makin tingginya jumlah kehamilan tidak diinginkan (KTD) pada remaja, data Kehamilan tidak diinginkan pada remaja menunjukkan ada kecenderungan meningkat dari 150.000 menjadi 200.000 kasus setiap tahun.
Beberapa survey yang dilakukan pada Sembilan kota besar di Indonesia menunjukkan kehamilan tidak diinginkan (KTD) mencapai 37.000 kasus, 27 persen diantaranya terjadi dalam lingkungan pranikah dan 12,5\% pada kelompok pelajar.

Adanya angka Kehamilan tidak diinginkan (KTD) terutama kehamilan pranikah dikalangan remaja memiliki hubungan yang sangat erat dengan meningkatnya jumlah aborsi. Kasus aborsi angkanya melaju sangat cepat bahkan melebihi jumlah aborsi di negara maju sekalipun. Jumlah kasus Selain aborsi, kehamilan tidak diinginkan (KTD) pada remaja juga menjadi penyumbang terbesar pernikahan dini remaja. Terbukti bahwa 90 persen pemohon dispensasi nikah 
dikarenakan perempuan menjadi korban kehamilan tidak diinginkan (KTD). Korban kehamilan tidak diinginkan (KTD) yang dipaksa menikah dengan pelaku berpotensi mengalami kekerasan berlapis, fisik, psikis dan ekonomi.

Strategi yang dikembangkan yaitu strategi interprofesional education (IPE) yaitu pendekatan proses pendidikan dua atau lebih disiplin ilmu yang berbeda berkolaborasi dalam proses belajar menjagar untuk membina interdisipliner dengan tujuan untuk meningkatkan praktek masing-masing. ${ }^{1}$ Alasan dilakukan metode ini karena disesuaikan dengan karakteristik remaja yang lebih percaya dengan temannya, sehingga lebih efektif untuk memberi pemahaman kepada remaja terkait kesehatan reproduksi khususnya bahaya kehamilan tidak diinginkan.

\section{Metode Penelitian}

Penelitian ini menggunakan desain pre eksperimental (dengan rancangan One Group Pretest Posttest 2. Pada penelitian ini diberikan perlakuan berupa pemberian model interprofesional education (IPE) kesehatan reproduksi remaja dalam pencegahan kehamilan tidak diinginkan (KTD) selama 1 kali terhadap responden.

Populasi dalam penelitian ini adalah siswa dan siswi kelas XI SMA Negeri Kota Pekalongan. Sampel yang diambil dalam penelitian ini sejumlah 60 siswa/siswi. Pengambilan sampel secara purposive sampling yaitu tehnik penentuan sampel dengan pertimbangan tertentu sesuai yang dikehendaki peneliti ${ }^{3}$. Instrumen penelitian ini menggunakan modul Pencegahan KTD, alat peraga orgam reproduksi manusia, alat tulis dan kuesioner tertutup. Uji validitas menggunakan uji korelasi item total (Item Total Correlation) dan teknik korelasi menggunakan product moment dengan nilai korealsi 0,361. uji reliabilitas dengan menggunakan Alpha Chronbach dengan nilai alpha pengetahuan 0,948 dan nilai alpha sikap 0,876. Uji normalitas menggunakan Kolmogorov---smirnov. Pada variabel pengetahuan sebelum perlakuan diperoleh $\mathrm{p}$ $\leq 0.05 \quad(0,05 \leq 0.05)$ dan setelah perlakuan didapatkan $\mathrm{P}<0,05(0,01 \leq 0.05)$, maka data pengetahuan sebelum dan setelah perlakuan termasuk data bersistribusi tidak normal dan variabel sikap sebelum perlakuan diperoleh $\mathrm{p}$ $>0,05(0,2>0,05)$ dan setelah perlakuan diperoleh $p>0,05(0,2>0,05)$, maka data sebelum dan setelah perlakuan termasuk data berdistribusi normal. Selanjutnya data pengetahuan yang terkumpul dilakukan analisis menggunakan uji statistik menggunakan non parametrik wilcoxon dengan menggunakan SPSS versi 16.

\section{Hasil dan Pembahasan}

\section{a. Karakteristik Responden}

Karakteristik responden berdasarakan jenis kelamin yaitu 39 responden (65\%) perempuan, berusia kurang dari 17 tahun yaitu 43 responden $(71,7 \%)$, sudah mengalami menstruasi atau mimpi basah sejumlah 59 responden $\quad(98,3 \%)$, berdomisili di kota Pekalongan sejumlah 54 responden (90\%), ayah responden berpendidikan SMA sejumlah 26 responden $(21,7 \%)$, pendidikan ibu responden yaitu SMA sejumlah 27 responden $(45 \%)$, pekerjaan ayah sebagai wirasawasta sejumlah 32 responden $(53,3 \%)$ dan pekerjaan ibu sebagai lainlain sejumlah 48 responden (80\%).

\section{b. Analisis Deskriptif Pengetahuan Responden \\ Gambar 1 Distribusi Pengetahuan Responden tentang kesehatan reproduksi remaja dalam pencegahan kehamilan tidak diinginkan (KTD)}

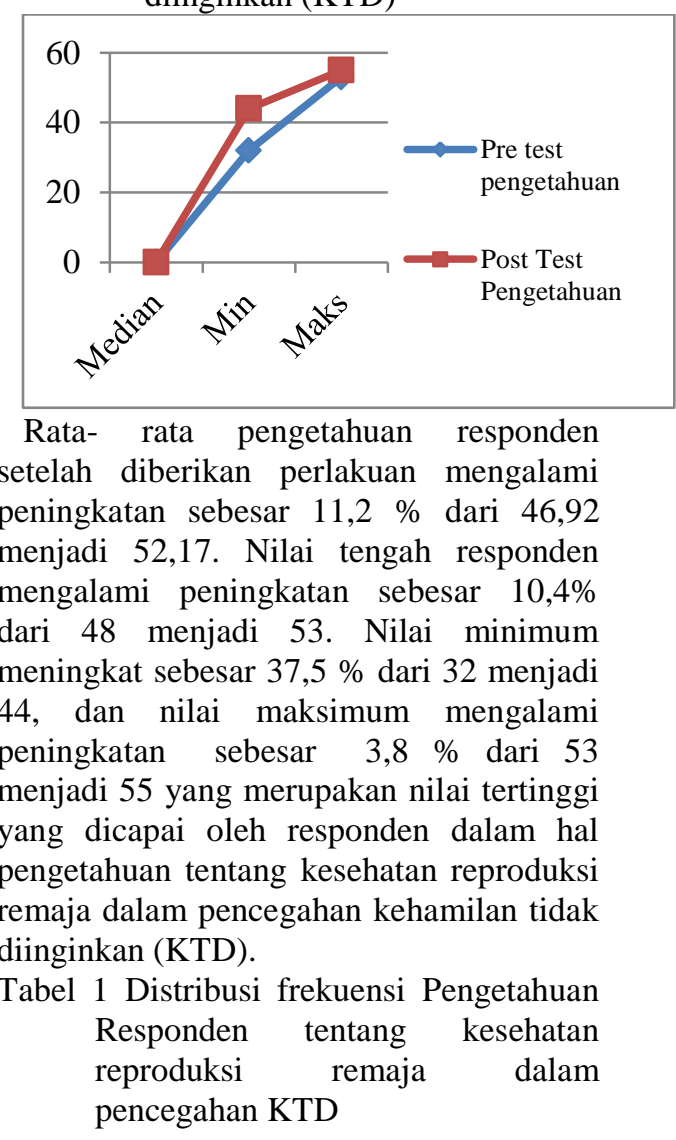

\begin{tabular}{llcc}
\hline No & Pengetahuan & Sebelum & Setelah \\
\hline 1. & Baik & 53 & 60 \\
& & $(88,3 \%)$ & $(100 \%)$ \\
2 & Cukup & 7 & 0 \\
& & $(11,7 \%)$ & $(0 \%)$
\end{tabular}


Hasil analisis data penelitian mengenai tingkat pengetahuan menjelaskan bahwa responden telah memiliki pengetahuan baik pada pre test dan meningkat lebih baik dengan peningkatan nilai pengetahuan pada post test.

Dengan demikian peneliti menyatakan bahwa pemberian model Interprofesional Education (IPE) berpengaruh terhadap tingkat pengetahuan kesehatan reproduksi remaja dalam pencegahan kehamilan tidak diinginkan (KTD) pada siswa SMA Negeri di Kota Pekalongan.

Peningkatan pengetahuan membuktikan bahwa pengetahuan merupakan hasil dari seseorang menangkap informasi dengan penginderaan terhadap suatu objek, dimana pada penelitian ini responden diberikan model Interprofesional Education (IPE) dengan narasumber dari profesi bidan dan perawat, modul Pencegahan Kehamilan Tidak Diinginkan (KTD), alat peraga organ reproduksi wanita dan laki-laki serta kuesioner tertutup. Penelitian ini menjelaskan bahwa terdapat perbedaan yang cukup jelas mengenai tingkat pengetahuan sebelum dan sesudah diberikan model Interprofesional Education (IPE).

Hasil jawaban responden yang masih kurang sebelum perlakuan (pre test) tentang organ reproduksi wanita dan pria masih ada jawaban yang rendah yaitu 50\% responden mengatakan wanita dapat mencegah kehamilan dengan cara makan nanas setelah melakukan hubungan intim/sex/ML, $50 \%$ responden wanita dapat menjadi hamil walaupun saat melakukan hubungan intim/seks/ML si pria mengeluarkan sperma di luar/buang luar (BL).

Hasil jawaban responden yang sudah benar semua setelah perlakuan (post test) tentang definisi kesehatan reproduksi, organ reproduksi wanita yaitu ovarium, definisi tentang dismenorhoe, tanda-tanda pubertas pada laki-laki ( tumbuh jakun di leher, suara membesar), tanda-tanda pubertas pada perempuan ( mentruasi, pinggul membesar), kehamilan dapat terjadi saat wanita melakukan hubungan intim/sex/ML untuk pertama kalinya dan wanita dapat hamil bila melakukan hubungan seksual hanya satu kali saja.

Pengetahuan merupakan hal yang sangat penting dalam proses terbentuknya tindakan seseorang. Seseorang harus tahu terlebih dahulu arti dan manfaat perilaku bagi dirinya, kemudian seseorang akan mengadopsi perilaku baru. Dan perilaku yang didasari pengetahuan akan lebih lama dan sebaliknya. ${ }^{4}$

Sedangkan menurut Kusumastuti (2010) mengemukakan bahwa pendidikan kesehatan reproduksi remaja oleh pendidik sebaya memberikan pengetahuan yang diharapkan dapat merubah sikap. ${ }^{5}$ Menurut Amrillah (2006), semakin tinggi pengetahuan kesehatan reproduksi remaja maka semakin rendah perilaku seksual pranikahnya dan sebaliknya semakin rendah pengetahuan kesehatan reproduksi yang dimiliki remaja maka semakin tinggi perilaku seksual pranikahnya. ${ }^{6}$

Pengetahuan yang tercakup dalam domain kognitif memiliki 6 tingkatan yaitu : tahu (know), memahami (comprehension), aplikasi (application), analisis (analysis), sintesis (synthesis) dan evaluasi (evaluation). ${ }^{7} \quad$ Peningkatan pengetahuan dapat dilakukan dengan pemberian interprofesional education (IPE) dari berbagai profesi yaitu perawat dan bidan.

Faktor-faktor yang mempengaruhi tingkat pengetahuan seseorang antara lain : pendidikan dan pekerjaan. Pendidikan dibangku sekolah bukan satu-satunya faktor yang mempengaruhi pengetahuan seseorang tetapi ada beberapa faktor pendukung eksternal yang secara langsung dapat mempengaruhi pengetahuan seperti pengalaman yang pernah dialami masa lalu, kebudayaan lingkungan sekitar dan media massa yang memberikan kemudahan seseorang untuk memperoleh pengetahuan yang baru ${ }^{8}$

Menurut Notoatmodjo bahwa pengetahuan seseorang terhadap objek mempunyai intensitas dan tingkat yang berbeda-beda. ${ }^{9}$ Salah satu upaya dalam meningkatkan pengetahuan remaja tentang kesehatan reproduksi dalam mencegah kehamilan tidak diinginkan (KTD) adalah melalui pemberian interprofesional education (IPE) dari berbagai profesi yaitu perawat dan bidan.

\section{c. Analisis Deskriptif Sikap Responden}

Gambar 2. Distribusi sikap Responden

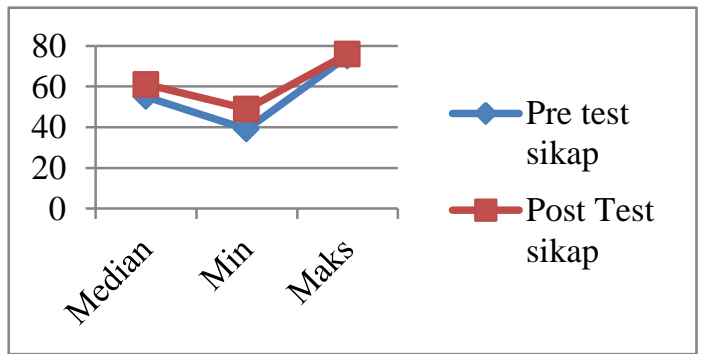


Nilai rata- rata sikap responden setelah perlakuan mengalami peningkatan sebesar $32 \%$ dari 46,27 menjadi 60,98. Nilai tengah mengalami peningkatan sebesar $10,9 \%$ dari 55 menjadi 61. Nilai minimum meningkat sebesar $25,6 \%$ dari 39 menjadi 49, dan nilai maksimum mengalami peningkatan sebesar $0,1 \%$ dari 75 menjadi 76 yang merupakan nilai tertinggi yang dicapai oleh responden dalam hal sikap tentang kesehatan reproduksi remaja dalam pencegahan kehamilan tidak diinginkan (KTD).

Berdasarkan hasil uji normalitas data pada variabel sikap sebelum perlakuan (pre test) diperoleh nilai $\mathrm{p}$ value $=0,2$ (pvalue > 0,05). Sehingga data berdistribusi normal. Kategori sikap dibagi menjadi 2 yaitu positif jika skor $\geq 46,27$ dan sikap negatif jika skor $<46,27$. Pada variebel sikap setelah perlakuan (post test) diperoleh nilai $p$ value $=0,2$ ( $p$ value $>0,05)$, sehingga data bersistrubusi normal. Kategori sikap dibagi menjadi 2 yaitu sikap positif jika skor $\geq 60,98$ dan sikap negatif jika skor $<60,98$.

Tabel 2. Distribusi frekuensi Sikap Responden tentang kesehatan reproduksi terhadap pencegahan kehamilan tidak diinginkan (KTD)

\begin{tabular}{|c|l|c|c|}
\hline No & Sikap & Sebelum & Setelah \\
\hline 1. & $\begin{array}{l}\text { Sikap } \\
\text { positif }\end{array}$ & $27(45 \%)$ & $31(51,7 \%)$ \\
2. & $\begin{array}{l}\text { Sikap } \\
\text { negatif }\end{array}$ & $33(55 \%)$ & $29(48,3 \%)$ \\
\hline
\end{tabular}

Dalam kuesioner terdapat 16 pernyataan mengenai sikap seksualitas sebelum perlakuan sebagai berikut : 76,6\% responden tidak setuju hubungan seks pranikah sebaiknya dilakukan dengan pacar tetap, 76,7\% responden tidak setuju hubungan sex pranikah lebih baik dilakukan dengan pekerja seks (PSK), $78,3 \%$ responden homoseksual adalah perilaku yang ditentang oleh massyarakat. Mayoritas jawaban yang positif terhadap kesehatan reproduksi remaja dalam pencegahan kehamilan tidak diinginkan (KTD) semakin meningkat secara signifikan setelah diberikan perlakuan. Namun masih ada jawaban responden yang masih negatif terhadap kesehatan reproduksi remja yaitu $11,7 \%$ responden setuju menggunakan kontrasepsi bertujuan untuk mencegah kehamilan, $60 \%$ responden seruju hubungan sex bertujuan untuk menjalin dan mempererat hubungan dengan pasangannya (relasional), 63,3\% responden setuju bahwa prostitusi (pelacuran) adalah perbuatan tidak normal.

Pemberian model Interprofesional Education (IPE) oleh peneliti kepada responden menunjukkan bukti adanya peningkatan sikap positif dan penurunan sikap negatif terhadap kesehatan reproduksi remaja dalam pencegahan kehamilan tidak diinginkan (KTD). Hal ini sesuai dengan pendapat Azwar (2007), bahwa salah satu faktor yang dapat mempengaruhi pembentukan sikap seseorang yaitu orang lain yang dianggap penting. Seseorang akan cenderung memiliki sikap yang konformis atau searah dengan orang yang dianggap penting. ${ }^{10}$

Peningkatan sikap positif pada responden dapat dipengaruhi oleh pengetahuan yang meningkat dan menjadikan responden dapat berubah sikap yang pada pre test masih buruk, pada saat post test berubah menjadi baik. Hal ini dikarenakan sikap responden yang menerima dan merespon pemberian pendidikan kesehatan dengan baik. Didukung oleh penelitian yang dilakukan oleh Andarini dan Purnamasari (2012) bahwa remaja yang memiliki informasi yang benar mengenai kesehatan reproduksi cenderung memiliki sikap dan tingkah laku yang bertanggung jawab dilihat dari penurunan tingkat perilaku merokok setelah adanya perlakuan berupa pemberian informasi kesehatan reproduksi terhadap responden. ${ }^{11}$

Terdapat penurunan skor sikap negatif pada responden Pre Test dan Post Test yaitu dari memiliki sikap negatif yang tinggi pada Pre Test dan kemudian menjadi menurun pada Post Test, artinya sikap negatif yang dimiliki responden cenderung menurun setelah dilakukan pemberian Model Interprofesional Education (IPE), Pre Test dan Post Test.

Hal ini ditunjang oleh pengetahuan responden. Sarwono (2011) menyatakan sikap dibentuk melalui proses belajar sosial di mana individu memperoleh informasi dari orang lain. Salah satu faktor yang berhubungan signifikan dengan perilaku berisiko pada remaja antara lain sikap. Sikap dapat menimbulkan cara berpikir tertentu dalam masyarakat dan cara berpikir ini mempengaruhi tindakan untuk membuat keputusan. ${ }^{12}$ Mubarak dalam Fitriani (2011) menyatakan bahwa dalam merubah sikap dapat dilakukan pembinaan melalui pendidikan kesehatan. 
Sikap sebagai suatu kecenderungan mental atau perasaan yang relative terhadap suatu kategori objek, orang atau situasi tertentu. ${ }^{14}$ Terdapat 4 tingkatan sikap yaitu menerima (receiving), menanggapi (responding), menghargai ( valuing) dan bertanggung Jawab (responsible) ${ }^{4}$

Pembentukan sikap berhubungan erat dengan pembentukan pengetahuan. Pengetahuan remaja meningkat mendorong terbentuknya sikap. Muchlas (1997) berpendapat bahwa pembentukan sikap diperoleh melalui proses belajar yang dapat terjadi karena pribadi terhadap orang, benda maupun peristiwa dan melalui proses belajar social seperti informasi yang diperolah dari orang lain. ${ }^{15}$

\section{d. Pengaruh Perlakuan pada Responden}

1. Perbedaan pengetahuan sebelum dan setelah perlakuan.

Tabel 3 Hasil Uji Beda pada variable pengetahuan sebelum dan sesudah perlakuan.

\begin{tabular}{|c|c|c|c|c|c|c|}
\hline No & $\begin{array}{c}\text { Vari } \\
\text { abel }\end{array}$ & $\begin{array}{c}\text { Nilai } \\
\text { Mean } \\
\text { sebelum } \\
\text { perlakuan }\end{array}$ & $\begin{array}{c}\text { Nilai } \\
\text { mean } \\
\text { setelah } \\
\text { perlaku } \\
\text { an }\end{array}$ & $\begin{array}{c}\text { kore } \\
\text { lasi }\end{array}$ & $\begin{array}{c}\text { Me } \\
\text { an }\end{array}$ & $\begin{array}{c}\text { signifik } \\
\text { ansi uji } \\
\text { inferen } \\
\text { sial }\end{array}$ \\
\hline 1. & $\begin{array}{l}\text { Peng } \\
\text { etahu } \\
\text { an }\end{array}$ & 46,92 & 52,17 & $\begin{array}{c}0,55 \\
6\end{array}$ & $\begin{array}{c}-5,2 \\
50\end{array}$ & 0,000 \\
\hline
\end{tabular}

Dari tabel diatas dapat diketahui bahwa variabel pengetahuan sebelum perlakuan diperoleh mean 46,92 dan rata-rata setelah perlakuan diperoleh 52,17 . Rerata nilai pengetahuan sebelum perlakuan mengalami peningkatan setelah perlakuan yaitu pemberian interprofesional education (IPE). Nilai korelasi antara variabel pengetahuan sebelum perlakuan dengan hasil 0,556 artinya memiliki hubungan sedang. Tingkat signifikansi hubungan 0,000 artinya signifikan pada level 0,01 . Nilai $p$ value $=0,000$ $(\mathrm{p}<0,05)$ yang artinya ada perbedaan pengetahuan antara sebelum dan setelah diberikan interprofesional education (IPE) kesehatan reproduksi remaja dalam pencegahan kehamilan tidak diinginkan (KTD). Nilai Mean diperoleh 5,250. Bernilai negatif artinya terjadi kecederungan kenaikan pengetahuan setelah diberikan perlakuan Interprofesional Education (IPE).

Hasil penelitian diatas menunjukkan perbedaan pengetahuan

sebelum dan setelah perlakuan, yaitui adanya kenaikan pengetahuan setelah diberikan model interprofesional education (IPE) terhadap kesehatan reproduksi remaja dalam pencegahan kehamilan tidak diinginkan (KTD) oleh perawat dan bidan. Hal ini berarti pemberian Interprofesional education (IPE) kesehatan reproduksi remaja dalam pencegahan kehamilan tidak diinginkan (KTD) melalui modul Pencegahan Kehamilan Tidak Diinginkan (KTD) dan Alat Peraga Organ Reproduksi Manusia (perempuan dan laki-laki), dapat dikatakan efektif terhadap peningkatan pengetahuan kesehatan reproduksi remaja dalam pencegahan Kehamilan Tidak Diinginkan (KTD) pada siswa SMAN Kota Pekalongan tersebut dengan nilai $p=0,000(p \leq 0,05)$.

Alat bantu atau peraga adalah alatalat yang digunakan oleh pendidik dalam menyampaikan bahan pendidikan atau pengajarannya. Keuntungan penggunaan media adalah sebagai berikut: (1) menimbulkan minat sasaran pendidikan; (2) mencapai sasaran yang lebih banyak; (3) membantu dalam mengatasi bannyak hambatan dalam pemahaman; (4) merangsang sasaran pendidikan untuk meneruskan pesan-pesan yang diterima kepada orang lain; (5) mempermudah penyampaian bahan pendidikan atau informasi oleh pendidik; (6) mempermudah penerimaan informasi oleh sasaran pendidikan; (7) mendorong keinginan orang untuk mengetahui, kemudian lebih mendalami dan akhirnya mendapatkan pengertian yang lebih baik; (8) membantu menegakkan pengertian yang diperoleh. ${ }^{16}$

Pengetahuan

reproduksi juga berarti memberdayakan kaum muda untuk mengetahui dan menjalankan hak mereka termasuk hak untuk menunda pernikahan dan hak untuk menolak seksual yang tidak diinginkan. ${ }^{17}$ Kesehatan reproduksi perlu diberikan kepada remaja, agar memiliki pengetahuan dan informasi yang benar, sehingga diharapkan dapat memiliki sikap dan perilaku yang bertanggung jawab terhadap proses reproduksi. ${ }^{18}$ Kesehatan reproduksi remaja yang tepat diperlukan untuk meningkatkan pengetahuan kesehatan reproduksi 
khususnya pada remaja, selain metode yang tepat sebaiknya pengetahuan kesehatan reproduksi dimasukkan dalam kurikulum sekolah bersama dengan pengetahuan kesehatan remaja lainnya.

Menurut pendapat Notoatmodjo bahwa pengetahuan seseorang terhadap objek mempunyai intensitas dan tingkat yang berbeda-beda. ${ }^{9}$ Salah satu upaya dalam meningkatkan pengetahuan remaja tentang kesehatan reproduksi dalam mencegah kehamilan tidak diinginkan (KTD) adalah pemberian model interprofesional education (IPE). Interprofesional Education (IPE) adalah suatu pelaksanaan pembelajaran yang diikuti oleh dua atau lebih profesi yang berbeda untuk meningkatkan kolaborasi dan kualitas pelayanan dan pelaksanaannya dapat dilakukan dalam semua pembelajaran, baik itu tahap sarjana maupun tahap pendidikan klinik untuk menciptakan tenaga kesehatan yang profesional. ${ }^{1}$

Interprofesional Education (IPE) terjadi ketika dua atau lebih profesi kesehatan belajar bersama, belajar dari profesi kesehatan lain, dan mempelajari peran masing-masing profesi kesehatan untuk meningkatkan kolaborasi dan kualitas pelayanan kesehatan.$^{19}$

2. Perbedaan sikap sebelum dan setelah perlakuan .

Tabel 4 Hasil Uji Beda pada variable sikap sebelum dan sesudah perlakuan.

\begin{tabular}{|c|l|c|c|c|c|c|}
\hline No & Variabel & $\begin{array}{c}\text { Nilai } \\
\text { Mean } \\
\text { sebelum } \\
\text { perlakuan }\end{array}$ & $\begin{array}{c}\text { Nilai } \\
\text { mean } \\
\text { setelah } \\
\text { perlakuan }\end{array}$ & $\begin{array}{l}\text { Korela } \\
\text { si }\end{array}$ & Mean & $\begin{array}{c}\text { signifikansi } \\
\text { uji } \\
\text { inferensial }\end{array}$ \\
\hline 1. & Sikap & 56,27 & 60,98 & 0,549 & $-4,717$ & 0,000
\end{tabular}

Dari tabel diatas dapat diketahui bahwa variabel sikap diperoleh nilai mean sebelum perlakuan nilai korelasi antara variabel sikap sebelum perlakuan dengan sikap setelah perlakuan diperoleh hasil 0,549 artinya memiliki hubungan sedang. Tingkat signifikansi hubungan 0,000 artinya signifikan pada level 0,01 . Nilai $p$ value $=0,000(\mathrm{p}<0,05)$ yang artinya ada perbedaan sikap antara sebelum dan setelah diberikan model interprofesional education (IPE) kesehatan reproduksi remaja dalam pencegahan kehamilan tidak diinginkan (KTD). Nilai Mean diperoleh 4,717. Bernilai negatif artinya terjadi kecederungan kenaikan sikap setelah diberikan perlakuan IPE. Rata-rata kenaikannya adalah 4,717.

Pendidikan kesehatan merupakan suatu upaya atau kegiatan untuk menciptakan perilaku masyarakat yang kondusif untuk kesehatan. Artinya, masyarakat menyadari atau mengetahui bagaimana cara memelihara kesehatan dan menghindari atau mencegah halhal yang merugikan kesehatan.$^{20}$ Berdasarkan penelitian yang dilakukan oleh Wahdini (2013), yang meneliti pengaruh penyuluhan oleh tenaga pelaksana gizi dengan metode ceramah disertai media poster dan leaflet terhadap perilaku ibu dan pertumbuhan balita gizi kurang dikecamatan Tanjung Beringin, dengan kesimpulan bahwa penyuluhan dengan metode ceramah disertai media poster dan penyuluhan dengan metode ceramah disertai media lieflet dapat meningkatkan pengetahuan dan sikap ibu balita. ${ }^{21}$

Sependapat dengan penelitian yang dilakukan oleh Dyeri, dkk (2017) yang mengatakan bahwa terdapat peningkatan sikap ibu tentang kesehatan balita setelah diberikan penyuluhan secara interprofesi oleh mahasiswa tenaga kesehatan. Kolaborasi antar tenaga kesehatan sangat diperlukan dalam pelaksanaan kelas ibu balita sehingga pengetahuan, sikap dan ketrampilan ibu terhadap kesehatan balita akan meningkat. ${ }^{22}$

Hasil penelitian ini juga sejalan dengan penelitian yang dilakukan oleh Dina, dkk (2014) yang menyatakan bahwa ada pengaruh yang signifikan antara pemberian interprofesional education (IPE) dengan perubahan sikap mahasiswa untuk belajar bekerja sama intraprofesi dalam keperawatan antenatal. ${ }^{23}$

\section{Simpulan}

a. Karakteristik responden berdasarakan jenis kelamin yaitu 39 responden $(65 \%)$ perempuan, berusia kurang dari 17 tahun yaitu 43 responden $(71,7 \%)$, sudah mengalami menstruasi atau mimpi basah sejumlah 59 responden (98,3\%), berdomisili di kota Pekalongan sejumlah 54 responden (90\%), ayah responden berpendidikan SMA sejumlah 26 responden $(21,7 \%)$, pendidikan ibu responden yaitu SMA sejumlah 27 responden (45\%), pekerjaan ayah sebagai wirasawasta sejumlah 32 responden $(53,3 \%)$ dan pekerjaan ibu 
sebagai lain-lain sejumlah 48 responden $(80 \%)$.

b. Ada perbedaan pengetahuan signifikan sebelum dan setelah perlakuan dengan nilai $\mathrm{p}$ value pengetahuan $=0,000$, memilik hubungan sedang ( nilai korelasi 0,556), rata-rata kenaikan pengetahuan 5,25.

c. Ada perbedaan sikap signifikan sebelum dan setelah perlakuan dengan nilai $\mathrm{p}_{\text {value }}$ pengetahuan $=0,000$, memiliki hubungan sedang (korelasi 0,549), ratarata kenikan sikap 4,717

\section{Daftar pustaka}

[1] American Collage of Clinical Pharmacy (ACCP). 2009. Interprofesional Education (Principle and application, a frame work for clinical pharmacy).

[2] Sugiyono. 2009. Metode Penelitian Kuantitatif, Kualitatif dan R \&D. Bandung : Alfabeta

[3] Setiadi. 2013. Konsep dan Praktek Penulisan Riset Keperawatan (Ed.2). Yogyakarta : Graha Ilmu.

[4] Notoatmodjo,S. 2007. Promosi Kesehatan dan Ilmu Perilaku, Jakarta : Rineka Cipta.

[5] Kusumastuti, FAD. 2010. Hubungan antara penegtahuan dengan sikap seksual pranikah remaja .[Karya Tulis Ilmiah]. Surakarta : Fakultas Kedokteran Universitas Sebelas Maret.

[6] Amrillah, R. 2006. Perbedaan Perilaku terhadap Hubungan Seksual Pranikah ditinjau dari Peran Keluarga, http://etd.library.ums.ac.id/go.SI-2007.

[7] Effendy,N. 1995. Perawatan Kesehatan Masyarakat. Jakarta : EGC.

[8] Wijayanto, Budi. 2013. Pengaruh Pemberian Pendidikan kesehatan reproduksi Remaja terhadap Pengetahuan tentang Perilaku Seksual di Desa Cepogo. Kecamatan Kembang. Kabupaten Jepara. Jurnal Keperawatan Komunitas.

[9] Notoatmodjo. 2005. Promosi Kesehatan Teori dan Aplikasi. Jakarta: Rineka Cipta.

[10] azwar, saifuddin. 2007. sikap manusia teori dan pengukurannya. yogyakarta : pustaka pelajar.

[11] andarini, purnamasari.2012. efektifitas pemberian informasi kesehatan reproduksi remaja terhadap penurunan perilaku merokok pada remaja putri. journal of consulting and clinica psychology. vol.74. no.4. yogyakarta : universitas mercu buana biana

[12] sarwono., s. 2011. psikologi remaja. jakarta : pt raja grafindo.

[13] Fitriani, S. 2011. Promosi Kesehatan. Yogyakarta : Graha Ilmu
[14] Loserch.C. Kopp B, Petty RE. 2007. Attitude Change in : Baumeister RF, Vohs KD editors. Encyclopedia of social Psychology. Thausand Oaks, CA : SAGE Publication

[15] Muchlas, M. 1997. Perilaku Organisasi (Organized Behaviour). Yogyakarta. PT Karipta Yogyakarta

[16] Notoatmodjo, soekidjo. 2003. Pendidikan dan Perilaku Kesehatan. Jakarta PT Rineka Cipta.

[17] UNFPA. 2014. Comprehensive Sexuality Education (online). United Nations population Fund. Available :http//www.unfa.org/comprehensivesexuality-education .accesed 3 Agsustun 2019.

[18] Departemen Pendidikan dan Kebudayaan.1997. Pedoman Pelatihan dan Modul Pendidikan Sebaya dalam Rangka Pendidikan Pencegahan HIV/AIDS di Lingkungan Perguruan Tinggi. Jakarta: Depdikbud.

[19] CAIPE. 2002. Interprofesional Education : A Definition. London : CAIPE

[20] Notoatmodjo, S. 2012. Promosi Kesehatan dan Perilaku Kesehatan. Jakarta : PT Rineka Cipta.

[21] Wahdini.2013. Pengaruh Penyuluhan oleh Tenaga Pelaksana Gizi dengan Metode Ceramah Disertai Poster dan Leaflet terhadap Periaku Ibu dan Pertumbuhan Baita Gizi Kurang di Kecamatan Tanjung Beringin

[22] Dyeri, dkk. 2017. Penerapan Interprofesional Education (IPE) pada Kelas Ibu Balita oleh Mahasiswa Tenaga Kesehatan untuk meningkatkan Sikap Ibu terhadap Kesehatan Balita di Kota Cimahi. JSK.

[23] Dina, Zakiyatul Fuadah. 2014. Kesiapan Mahasiswa untuk Belajar Bekerjasama Interprofesi dalam Perawatan Anteanatal. Jurnal Ners : Universitas Gajah mada. 